of the theory of radio propagation and for his outstanding contributions to engineering education. The Institute of Radio Engineers of New York in 1955 also conferred on him the high honour of election to fellowship of the Institute.

His scientific work apart, Howe experienced his greatest enjoyment in his music. He was an accomplished violinist. He had been taught, he said, when very young on a miniature violin specially made for him, and he could not remember a time when he did not play the instrument. Until a year or two before his death he was an active member of the Glasgow University Orchestral Society.

Only those who had the good fortune to study under him knew the quality of his teaching. He was one of the greatest teachers of his generation. It is hard to escape the conclusion that the main driving force in his scientific work was the urge first to understand, in Clerk Maxwell's boyish phrase, "the go of the thing" and then to expound it. His mind was essentially scholarly, and yet one got the impression that he was intrigued by the unexpected practical implication, the apparent anomaly or the amusingly odd concept rather than by the deeper philosophical implications.

A lively and entertaining companion, a delightful host and an equally delightful guest, Prof. Howe had a wide circle of friends. It was only rarely that the brilliant mind, which in its day-to-day contacts with the world gave the impression of being quietly but confidently self-contained, revealed for a moment that depth of human feeling of which it was capable.

Prof. Howe married in 1901 Sarah Alice Maunder. Mrs. Howe died in 1930.

J. Greic

\section{Dr. Norman Bauer}

Not often is exceptional scientific ability and a deep concern for the welfare of his fellow man com. bined in one individual. Such an individual was Dr. Norman Bauer.

Dr. Bauer began his studies at the University of California at Berkeley, graduating with a B.S. in chemistry in 1937. He then entered the University of Michigan, receiving his M.S. in 1939 and his Ph.D. in 1941, under the direction of Prof. K. Fajans. $\mathrm{He}$ hold a scholarship during 1936-37 at the University of California and was Eastman Kodak Fellow at the University of Michigan during 1940-41, and a Post-doctoral Fellow at that institution during 194142.

Desiring to teach, he joined the faculty of the University of New Hampshire in 1942 and remained there until 1945. During this period he was coauthor with Prof. Fajans of the sections on the determination of density and refractometry in Weissberger's Technique of Organic Chemistry, having done much important research in these fields. Due to personal obligations, he returned to Califormia in 1945, where he was employed by the California Research Corporation. Here he became interested in mass spectrometry, publishing articles in this field. In 1949 he founded an independent research laboratory under the name Physical Science Associates at Berkeley. Later, with his personal obligations changed, he returned to academic life, accepting a position at Utah State University in 1953, where he was most recently professor of chemistry.

Here he carried on an excellent programme of teaching and basic research in physical chemistry.
His knowledge and enthusiasm encouraged research in several fields, and many new methods of approaching problems in soil and plant nutrition and in the. thermodynamics of the water relations of soils and plants were developed by him. He became interested in the problem of biological nitrogen fixation and made substantial progress in this difficult field, studying the physical chemistry of legaglobing (the proteins involved in nitrogen fixation), establishing a reputation for his laboratory in this topic. Recently, he made significant discoveries that may lead to a major advance in the solution of this problem. Working with olectron spin resonance equipment at Varian Laboratories during the summer of 1960 , he detected the presence of free radicals that could be key intermediates in nitrogen fixation. This was especially gratifying to him, since he had predicted theoretically the existence of such radicals in a study of possible pathways for the process. His death on September 9 prevented him from following up this important possibility.

Dr. Bauer was concerned about many problems involving man's welfare. He was opposed to further testing of atomic bombs and personally paid for advertising space to register his protest. He published articles questioning the reasoning of the U.S Atomic Energy Commission on the hazards of radioactive fall-out. He was particularly concerned with the dangers of nuclear war and spoke out strongly for the cause of peace. He was a champion of the cause of academic freedom, taking an active part in upholding the right of free inquiry. A dedicated scientist, a gifted teacher, he was, in every sense, a man of unquestioned integrity and morals who brought honour to his profession, and a man of good will. JACK T. SPENCE:

\section{Mr. Jaques Cattell}

JAQUeS CATTELl, editor of American Men of Science, publisher of the American N'aturalist, and president of the Jaques Cattell Press, Inc., died after' a long illness at New York Hospita] on December 18 ; he was fifty-six years old.

In $1923 \mathrm{Mr}$. Jaques Cattell became associate editor of American Men of Science with his father. the late Dr. James McKeen Cattell, and editor following the death of his father. He was also editor of Leaders in Education, founded by his father. The Directory of American Scholars was established. by him in 1942, under the sponsorship of the American Council of Learned Societies.

Mr. Jaques Cattell was interested in scientific publishing and the graphic arts. He was president of Science Press Printing Company, and later was a pioneer in the use of cold type composition in scientific publishing. In 1959 he moved to Arizona, and, at the invitation of the President of Arizona State University, continued the publication of his biographical directories from the University campus in Tempe.

$\mathrm{He}$ is survived by his widow, the former Elizabeth Walsh, and his son, James Cattell.

The Jaquos Cattell Press, Inc., has announced the: appointment of Garrison Cattell and Dorothy Hancock as acting editors of American Men of Science. Mr. Cattell and Mrs. Hancock have worked closely with Mr. Jaques Cattell in editing and publishing this directory. 